\title{
The Effect of Stable Manure and Seedling Number on Growth and Yield of Black Rice (Oryza sativa L. Indica)
}

\author{
Okti Herliana*, Ida Widiyawati and Sapto Nugroho Hadi \\ Laboratory of Agroecology, Department of Agrotechnology, Faculty of Agriculture, \\ Universitas Jenderal Soedirman, Purwokerto, Indonesia \\ ${ }^{*}$ Corresponding author: okti.herliana@unsoed.ac.id
}

\begin{abstract}
Black rice is one of fungtional food sources. The obstacle of its cultivation is availability of qualified seeds and organic fertilizers input. This research aimed to determine the effect of stable manure on growth and yield of black rice, to observe the effect of seddling number per planting hole and to obtain the best combination of stable manure and seedling number on the growth and yield of black rice. The research was conduct in rice field on Karanglewas Kidul village, Karanglewas district, Banyumas, Central Java during April until September 2016. This research used a split plot design, with 3 repetition. The main plot was three type of stable manure (chiken, goat and cow), while the subplot was seddling number (1, 2 and 3). Data was analyzed using ANOVA and DMRT at $p 0.05$ level. The results showed that chicken manure gave the highest productivity rice of 5.15 tons ha ${ }^{-1}$. The 1 seedling each hole gave the highest result on panicle length and grain number per panicle. The better combination treatment was chicken manure and three seedling per planting hole wich gave the highest grain yield of 5.38 tons ha ${ }^{-1}$.
\end{abstract}

Keywords: black rice, growth and yield, seedling number, stable manure

Cite this as: Herliana, O., Widiyawati, I., \& Hadi, S., N. (2019). The Effect of Stable Manure and Seedling Number on Growth and Yield of Black Rice (Oryza sativa L.Indica). Caraka Tani: Journal of Sustainable Agriculture, 34(1), 13-21. doi: http://dx.doi.org/10.20961/carakatani.v34i1.27098

\section{INTRODUCTION}

Rice plants is classified as a major cereal crop whose results are known as rice consumed as a staple food of almost the Indonesian people (Kristamtini et al., 2014). According to Chaudhary (2003), there are various colors of rice and the color depends on the color pigment, especially anthocyanin in the pericarp layer, seed coat or aleuron. According to Kristamtini (2009), there are 3 types of rice in the world, i.e white rice, red rice and black rice.

Black rice contains less protein and iron content $15.52 \mathrm{ppm}$ which higher than white rice from varieties of IR64, Ciherang, Cisadane, Sintanur, Pandanwangi and Batang Gadis which contain substances the iron ranges from 2.9 up to $4.4 \mathrm{ppm}$. Iron nutrient is needed by the body in the formation of red blood cells. Iron content in the rice can resolve anemia (Suardi and Ridwan, 2009).

Black rice is a local variety that contains the best pigments (especially anthocyanins), in contrast to white rice or other colors of rice. Black rice has a good taste, specific aroma and unique appearance. When it's cooked, black rice becomes thick with flavor and aroma that inspires appetite (Suardi and Ridwan, 2009). Black rice is known locally by people with different names, namely Wulung rice in Solo Central Java, Gadog rice in Cibeusi West Java, Cempo Ireng rice or Jlitheng rice in Sleman Yogyakarta and Melik rice in Bantul, Yogyakarta (Balai Besar Penelitian Tanaman Padi, 2013).

\footnotetext{
* Received for publication January 18, 2019

Accepted after corrections February 15, 2019
} 
Variety of black rice has not been widely planted and the adaptation in organic rice ecosystems is unknown. Meanwhile, needs for the increase of black rice should be continued in line with its function as a functional staple food and as a medicine, so this rice is more suitable to be produced from organic farming systems (Maulida and Arisoesilaningsih, 2013). In addition, effective technology is needed to increase the production of black rice, one of which is by regulating the number of seeds per planting hole and type of organic fertilizer.

Long term use of chemical fertilizer can reduce soil quality but the addition of only organic fertilizer will not be able to increase crop productivity. Integrated nutrient management system that is giving organic fertilizers and inorganic fertilizers as a balanced manner is an effort to implement sustainable agriculture that can increase land productivity as well as crop yields (Juarsah, 2014). Soil organic manure is the main source of soil nitrogen, its role is quite large in terms of physical, chemical and biological and environmental improvements. The nutrient content of organic fertilizers found in manure varies depend on the type of livestock, fodder, age and health of livestock. Other types are green manure, which can be in the form of crop residues or that are planted specifically as a producer of green manure, wild plants on the edge of land, roadside, or irrigation canals (Rachman et al., 2006).

The determination of plants number per planting hole is closely related to the level of plant population. Plant population density affects plant growth and production. In addition to save the use of seeds, it can also increase the development potential of puppies and ultimately obtain best production (Muyassir, 2012). According to Aliksa Organik SRI Consultan (2009), planting one seed per planting hole will provide an opportunity for seedlings to grow more shoots, provide freedom of movement and avoid competitive occurrence.

The results of Christanto and Agung's research (2014), showed that the seedling number per hole significantly affected the grains number of per panicle, the weight of 1,000 grain seeds, the weight of dry grain harvested and the harvest index. The highest yield of 4,387 tons $h^{-1}$ of harvested dry grain was obtained from the treatment of one seed per hole. Seedling treatments 1-3 stems per clump provide panicle length, number of grains per panicle, number of grained grains per panicle and weight of 1,000 seeds tends to be better than other treatments (Misran, 2017).

The utilization of stable manure and the seedling number per planting hole has not been widely applied to cultivate of black rice, so it is necessary to conduct research to find out the effective organic fertilizer and the optimal number of seeds per planting hole for black rice plants. This study aimed to determine the effect of stable manure, the effect seedling number per planting hole, as well as to obtain the better combination of stable manure and seedling number per planting hole on the growth and yield of black rice plants.

\section{MATERIALS AND METHOD}

This research was conducted at the paddy fields of Karanglewas Kidul Village, Karanglewas, Banyumas, Central Java, that located at coordinate of $7^{\circ} 25^{\prime} 32.9^{\prime \prime}$ South Latitude and $109^{\circ} 12^{\prime} 03.5^{\prime \prime}$ East Longitude an altitude of approximately 93 meters above sea level. The experimental site possessed Inceptisol soil type, daily temperature of $30.4{ }^{\circ} \mathrm{C}$, air humidity of $79.5 \%$ and monthly rainfall of $116.5 \mathrm{~mm}$. Observations of growth variables and grain yield were done in the field and the Laboratory of Agronomy and Horticulture, Faculty of Agriculture, Universitas Jenderal Soedirman, Purwokerto. This research covered approximately 6 months starting from April up to September 2016.

Materials used in this research were local varieties of Balinese rice seeds (source; Banyumas farmers), manure (cattle, goats and chickens), Bio-P60 as bio pesticide produced by Plant Protection Laboratory, Agricultural Faculty, Universitas Jenderal Soedirman and other supporting materials. The tools were used stationery, label paper, analytic digital scales type 801201 Mattler-10 Ledo AC, ruler, meter, hoe, bucket, stove, rope, nameplate, plastic bag, observation sheet and sprayer.

The field experiment used split plot design (SPD) with 2 factors consisted of type of manure and seedling number per planting hole, replicated three times. The main plot was stable manure types, namely chicken manure (P1), goat manure (P2), cow manure (P3), while the subplots were number of seedling per planting holes, namely one (B1), two (B2) and three seedlings per planting hole (B3). There were 9 combination treatments, 
namely P1B1, P1B2, P1B3, P2B1, P2B2, P2B3, $\mathrm{P} 3 \mathrm{~B} 1, \mathrm{P} 3 \mathrm{~B} 2$ and $\mathrm{P} 3 \mathrm{~B} 3$. The experimental unit was $2 \times 3 \mathrm{~m}^{2}$.

Research activities were: land tillage, make plots experiment, sifting stable manure and applying as organic fertilizers according to treatment. The seeds of black rice were planted for 21 days before transplanting. Fertilization is given 3 days before the seedling transferred to the land by using chicken, goats and cattle manure with dose 20 tons ha ${ }^{-1}$ similar to $12 \mathrm{~kg}$ of stable manure per plot. Application of stable manure per plot was $12 \mathrm{~kg}$. Plant maintenance includes weeding, irrigation, pest and diseases management. Measurements of growth variables were carried out during the final vegetative period and yields were carried out when harvesting and the plants were 120 day after planting.

The variables observed were plant height, number of productive tillers, number of leaves per clump, panicle length, number of grains per panicle, number of grain perforations, percentage of filled grains, dry grain weight per clump, weight of 1,000 grain and rice productivity. Data were analyzed using Analysis of Varians (F Test) and following by Duncan multiple range test (DMRT) with $p 0.05$.

\section{RESULTS AND DISCUSSION}

Matrix of Anova containing growth and yields variables of black rice that treated with stable manure and the seedling number per planting hole is presented in Table 1. The type of stable manure had affected significantly on plant height, productive tillers, number of leaves per clump, number of grains per panicle, dry grain weight per clump and grain yield. Meanwhile, the seedling number per planting hole only affected significantly on panicle length and number of grains per panicle. However, interaction between two treatments affected did not significantly different for all observed variables.

Table 1. Matrix of ANOVA results on variables of growth and yield of black rice

\begin{tabular}{lccc}
\hline \multirow{2}{*}{$\quad$ Variable } & \multicolumn{3}{c}{ Treatment } \\
\cline { 2 - 4 } Plant height (cm) & P & $\mathrm{B}$ & P X B \\
Productive tillers (stem) & $*$ & $\mathrm{~ns}$ & $\mathrm{~ns}$ \\
Number of leaves per clump (sheet) & $*$ & $\mathrm{~ns}$ & $\mathrm{~ns}$ \\
Panicle length (cm) & $\mathrm{ns}$ & $\mathrm{ns}$ & $\mathrm{ns}$ \\
Number of grains per panicle (grain) & $*$ & $*$ & $\mathrm{~ns}$ \\
Number of grain perforations per panicle (grain) & $\mathrm{ns}$ & $\mathrm{ns}$ & $\mathrm{ns}$ \\
Percentage of filled grains (\%) & $\mathrm{ns}$ & $\mathrm{ns}$ & $\mathrm{ns}$ \\
Dry grain weight per clump (g) & $*$ & $\mathrm{~ns}$ & $\mathrm{~ns}$ \\
Weight of 1,000 grain (g) & $\mathrm{ns}$ & $\mathrm{ns}$ & $\mathrm{ns}$ \\
Productivity (ton ha ${ }^{-1}$ ) & $*$ & $\mathrm{~ns}$ & $\mathrm{~ns}$ \\
\hline Nod
\end{tabular}

Note : $\mathrm{P}=$ stable manure; $\mathrm{B}=$ seedling number; $\mathrm{P}$ X B $=$ interaction between stable manure and seedling number; $*=$ significant at level $p 0.05 ; \mathrm{ns}=$ nonsignificant

\section{Effect of stable manure on the growth and yield of black rice}

The effect of stable manure on growth and yield of black rice plants is presented in Table 2 . Stable manure affected significant on plant height and number of leaves per clump and have a significant effect on productive tillers, number of grains per panicle, dry grain weight per clump and productivity. According to Kaya (2014), application of manure and NPK fertilizer can increase soil $\mathrm{pH}$, vegetative growth variables (plant height and productive tillers number), grain yield and yield components (number of filled grains per panicle and weight of 1,000 grains). Sari et al. (2014), reported that grain yields from applying manure 20 tons per ha and $100 \%$ dose of inorganic fertilizers increased by $24.19 \%$ compared to without applying manure.

Bachtiar et al. (2016), studied the effect of manure and SP-36 on the growth of lowland rice plants, stated that application of 100\% SP-36 and manure 20 tons per ha gave the highest value to plant height, tillers number, dry weight of biomass and dry grain yield. Application of manure combined with urea significantly affected increasing grain yield (Azis et al., 2012). 
Table 2. The effect of stable manure on growth and yield of black rice

\begin{tabular}{lrrr}
\hline \multirow{2}{*}{ Variabel } & \multicolumn{3}{c}{ Type of stable manure } \\
\cline { 2 - 4 } & \multicolumn{1}{c}{ P1 } & \multicolumn{1}{c}{ P2 } & \multicolumn{1}{c}{ P3 } \\
\hline Plant height (cm) & $101.82 \mathrm{a}$ & $91.02 \mathrm{~b}$ & $89.29 \mathrm{~b}$ \\
Productive tillers number & $16.40 \mathrm{a}$ & $13.42 \mathrm{~b}$ & $13.56 \mathrm{~b}$ \\
Number of leaves per clump (sheet) & $140.64 \mathrm{a}$ & $100.49 \mathrm{~b}$ & $97.40 \mathrm{~b}$ \\
Panicle length (cm) & $22.88 \mathrm{a}$ & $22.49 \mathrm{a}$ & $22.63 \mathrm{a}$ \\
Number of grains per panicle & $157.10 \mathrm{a}$ & $147.93 \mathrm{~b}$ & $147.64 \mathrm{~b}$ \\
Number of grain perforations per panicle & $74.70 \mathrm{a}$ & $72.42 \mathrm{a}$ & $80.49 \mathrm{a}$ \\
Percentage of filled grains (\%) & $52.97 \mathrm{a}$ & $51.64 \mathrm{a}$ & $46.66 \mathrm{a}$ \\
Dry grain weight per clump (g) & $40.49 \mathrm{a}$ & $32.47 \mathrm{~b}$ & $29.80 \mathrm{c}$ \\
Weight of 1,000 grain (g) & $21.88 \mathrm{a}$ & $23.36 \mathrm{a}$ & $22.45 \mathrm{a}$ \\
Productivity (ton ha h $^{-1}$ ) & $5.15 \mathrm{a}$ & $4.27 \mathrm{~b}$ & $3.93 \mathrm{c}$ \\
\hline
\end{tabular}

Note : $\quad$ P1 = chicken manure; P2 = goat manure; P3 = cow manure. Number followed by the same letter in same row is not significant at $p 0.05$ according to DMRT

Chicken manure has better effect compared to other on plant height and number of leaves per clump, as well as a significant effect on productive tillers, number of grains per panicle, dry grain weight per clump and productivity. The application of chicken manure could be yield the grains by 5.15 tons ha $^{-1}$ which was higher than goat and cow manure by 4.27 tons $\mathrm{ha}^{-1}$ and 3.93 tons $\mathrm{ha}^{-1}$, respectively (Table 2). The higher content of nitrogen and phosphorus in chicken manure causes better productivity than other manure. The difference of animal manure also varies of nutrients content (Samekto, 2006; Andayani and Sarido, 2013).

Table 3. Nutrients of cow, chicken and goat

\begin{tabular}{lccccc}
\hline Stable & \multicolumn{5}{c}{ Content (\%) } \\
\cline { 2 - 6 } Manure & $\mathrm{N}$ & $\mathrm{P}$ & $\mathrm{K}$ & $\mathrm{Ca}$ & $\mathrm{Mg}$ \\
\hline Cow & 2.33 & 0.61 & 1.58 & 1.04 & 0.33 \\
Chicken & 3.21 & 3.21 & 1.57 & 1.57 & 1.44 \\
Goat & 2.10 & 0.66 & 1.97 & 1.64 & 0.60 \\
\hline
\end{tabular}

Source: Samekto, 2006

Chicken manure has the higher nutrient content and decomposes faster than the same number of units as other manure (Hartatik and Widowati, 2005). The $\mathrm{N}$ element is a macro nutrient that plays an important role in the growth and various plant development processes (Hakeem et al., 2011), such as formation of chlorophyll, protoplasm, proteins and nucleic acids (Fahmi et al., 2010). Nitrogen requirement for plants is fulfilled to grow well. This is supported also by the research by Munawar (2011), that plants with enough nitrogen will grow well According to (Syakhril et al., 2014), nitrogen fertilization had a significant effect on plant height, panicle length, weight of 1,000 seeds and produce of 7.52 tons ha- ${ }^{-1}$.

Chicken manure has better quality because of high $\mathrm{P}$ content besides $\mathrm{N}$ and $\mathrm{K}$ (Masdar and Kasim, 2009). According to soil analyzed chicken manure have $2,473 \% \mathrm{C}$ organic, $0.094 \% \mathrm{P}$ total, $0,308 \% \mathrm{~N}$ total, $0,87 \% \mathrm{~K}$ total, higher than cow and goat manure based on soil analyzed at Laboratory of Land Resources, Agricultural Faculty, 2016. The phosphorus (P) is a macro nutrient that is needed by plants for various life processes such as photosynthesis, respiration, energy transfer and storage, cell division and enlargement and carbohydrate metabolism in plants (Salisbury and Ross, 1992).

According to Bustami et al. (2012), plant growth and crop production will reach optimum if growth supporting factors are in optimal condition, the intended elements are nutrients needed by plants, especially $\mathrm{N}, \mathrm{P}$ and $\mathrm{K}$ is in optimum condition, available to other plants and micro nutrients. Taiz and Zeiger (2002), also stated that phosphorus acts as a constituent of metabolites and complex compounds as activators and cofactors or compilers of enzymes. Syamsiyah et al. (2009), stated that P fertilization has a very real effect in increasing the yield of rice plants in sandy rice fields at the Kulon Progo beach, Yogyakarta province.

The type of stable manure did not affect the panicle length, number of grain perforations per panicle and the weight of 1,000 grains. It is thought that genetic effect is stronger than the effects of $\mathrm{N}, \mathrm{P}$ and $\mathrm{K}$ elements contained in 
manure. According to Rahayu and Harjoso (2011), plant growth and production are not only influenced by fertilizer application, but also by kind of cultivar. The cultivar used in this research is local Balinnese cultivar that responsive in Banyumas regency and some farmer cultivated it.

Effect of seedling number on the growth and yield of black rice

Table 4 presents that the seedling number only affected significantly to panicles length and the number of grains per panicle, but did not affect significantly to plant height, productive tillers, number of leaves per clump, number of grain perforations per panicle, percentage of filled grain, dry grain weight per clump, 1,000 grain weight and grain yield. The better panicle length is achieved on the treatment of one seedling with a length by $23.16 \mathrm{~cm}$. Treatment of one seedling also gave better number of grains per panicle (164.60 grains).

Table 4. Effect of number of seedling per planting hole on the growth and yield of black rice

\begin{tabular}{lrrr}
\hline \multirow{2}{*}{ Variable } & \multicolumn{3}{c}{ Seedling number } \\
\cline { 2 - 4 } & \multicolumn{1}{c}{ B1 } & \multicolumn{1}{c}{ B2 } & \multicolumn{1}{c}{ B3 } \\
\hline Plant height $(\mathrm{cm})$ & $95.89 \mathrm{a}$ & $91.78 \mathrm{a}$ & $94.04 \mathrm{a}$ \\
Productive tillers (stem) & $14.11 \mathrm{a}$ & $14.75 \mathrm{a}$ & $14.51 \mathrm{a}$ \\
Number of leaves per clump & $112.47 \mathrm{a}$ & $111.53 \mathrm{a}$ & $114.53 \mathrm{a}$ \\
Panicle length $(\mathrm{cm})$ & $23.16 \mathrm{a}$ & $22.63 \mathrm{~b}$ & $22.22 \mathrm{c}$ \\
Number of grains per panicle & $164.60 \mathrm{a}$ & $148.96 \mathrm{~b}$ & $139.11 \mathrm{c}$ \\
Number of grain perforations per panicle & $87.59 \mathrm{a}$ & $74.54 \mathrm{a}$ & $65.48 \mathrm{a}$ \\
Percentage of filled grains $(\%)$ & $47.65 \mathrm{a}$ & $50.34 \mathrm{a}$ & $53.29 \mathrm{a}$ \\
Dry grain weight per clump (g) & $34.63 \mathrm{a}$ & $34.99 \mathrm{a}$ & $33.14 \mathrm{a}$ \\
Weight of 1,000 grain $(\mathrm{g})$ & $22.14 \mathrm{a}$ & $22.56 \mathrm{a}$ & $22.99 \mathrm{a}$ \\
Productivity (ton ha $\left.{ }^{-1}\right)$ & $4.38 \mathrm{a}$ & $4.43 \mathrm{a}$ & $4.55 \mathrm{a}$ \\
\hline
\end{tabular}

Note : $\quad B 1=$ one seedling per planting hole; $B 2=$ two seedling per planting hole $; \mathrm{B} 3=$ three seedling per planting hole. Number followed by the same letter in the same row is no significant at $p 0.05$ according to DMRT

According to Misran (2017), use of large quantities of seedling make the quantities of panicle will be reduced, the percentage of empty grains will increase and the weight of 1,000 grains will be reduced. Susilo et al. (2015) stated that the fewer seedling per planting hole, panicles length tends will be longer. Factors in the number of seedling per planting hole showed significantly different results between treatments for panicle length. The number of 1 seedling per planting hole give the highest average panicle length of 23.16 $\mathrm{cm}$. This is because the small number of seeds can utilize nutrients, sunlight and water properly. According to Gani (2003), plant density can cause nutrient competition. Susilo et al. (2015) states that the number of seedling per fewer planting holes, nutrient absorption, sunlight and the air is more optimal, so make space for plants tiller formation and growth roots optimal. According to Gardner et al. (1991), plant growth and development are controlled by genetics, crop competition, leaf abortion, growing media atmosphere and soil $\mathrm{pH}$.

The number of seedling of 3 stems per clump can grow better than the number of less than 3 stems per clump, but because of competition between plants in the absorption of nutrients, so that it can suppress the growth and yield of rice plants. Lakitan (2000) stated that the number of seeds per clump tends to increase competition between plants in one clump for sunlight and nutrients so that it affects to the growth and production. Based on the results of various experiments, the effect of stable manure and number of seedling per hill on growth and yield of rice has been shown that 2 seedling per hill had significant impact on the grain yield with higher monetary return compared to others. This treatment not only gave higher grain yield but also had higher by net return and cost: benefit ratio. On this experimental used the seed of 18 day old seedling. Because the younger seedling has the capacity to early establishment and start growing at a faster rate due to higher root development leads to more nutrient uptake and weeds suppression ability in comparison to aged seedlings (Gurjar et al., 2018).

Seedling number per planting hole did not affect significantly or plant height. This is thought to be influenced by the genetic factors of the plant 
itself so that increasing of the seedling number per planting hole does not give a real difference in plant height. Susilo et al. (2015) states that plant height per clump is more influenced by genetic factors so the number of seeds does not affect to the plant height.

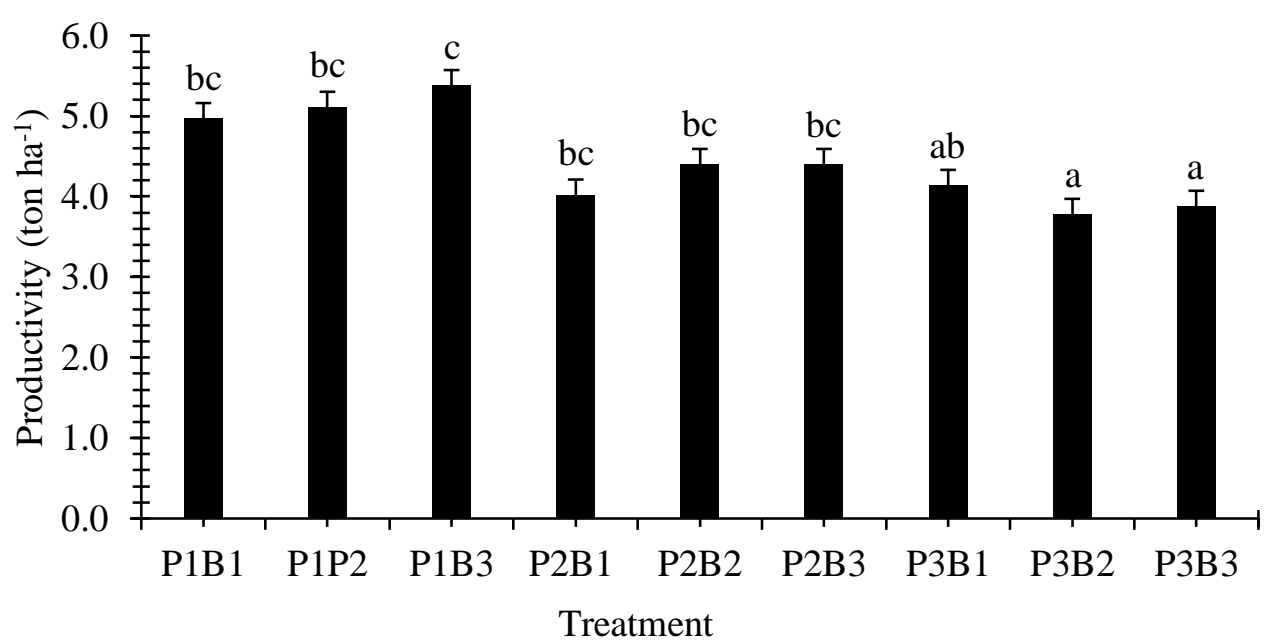

Figure 1. Combination of stable manure and seedling number on grain weight of black rice according to DMRT at $p 0.05$

Seedling number per planting hole also did not significantly affected to the crop production factors, i.e. productive tillers, dry grain weight per clump, weight of 1,000 grains and rice productivity. This condition caused by genetically type. This research used local black rice variety and grown in the same ecology. The shape, size and weight of seeds are determined by genetic factors (Hutasoit et al., 2015).

Thawait et al. (2014) observed that transplanting of 2-3 seedlings hill ${ }^{-1}$ in the spacing of $25 \mathrm{~cm} \times 25 \mathrm{~cm}$ recorded significantly highest plant height (129.64), number of tillers (15.70 tillers hill $\left.{ }^{-1}\right)$, dry matter accumulation $(102.65 \mathrm{~g}$ hill $^{-1}$ ) and yield attributing characters along with highest grain yield (3.820 tons $\mathrm{ha}^{-1}$ ) and straw yield (7.791 tons $\left.\mathrm{ha}^{-1}\right)$. Further research by Ehsanullah et al. (2012) observed the effect of seedlings density per hill have a strong influence on rice growth and grain yield due to competitive effects both on the vegetative and reproductive development. Panicle length, number of branches per panicle and kernels per panicle remained unaffected at varying levels of rice seedlings per hill. The number of 2,3 and 4 seedlings hill ${ }^{-1}$ resulted in maximum rice kernel on the yield and harvest index due to enhanced number of panicle bearing tillers and 1,000- kernel weight. Ahmad and Hasanuzzaman (2012) observed that the highest grain yield $\left(497 \mathrm{~g} \mathrm{~m}^{-2}\right)$ were observed in the treatment having combination of two seedling hill ${ }^{-1}$.

No interaction between type of stable manure and seedling number per planting hole was on productivity of black rice per hectare variables. The best combination of chicken manure treatment and the number of three seeds per planting hole with grain yield productivity by 5.38 tons ha $^{-1}$.

\section{CONCLUSIONS}

Chicken manure is the best type of organic fertilizer which gives productivity by 5.15 tons $\mathrm{ha}^{-1}$ and affects growth parameters of plant height, productive tillers, number of leaves per clump, number of grains per panicle, dry grain weight per clump). The best seedling number is three seeds per planting hole which gives grain yield by 4.55 tons $\mathrm{ha}^{-1}$. The best combination is chicken manure treatment and three seeds per planting hole that yield grains by 5.38 tons $\mathrm{ha}^{-1}$. 


\section{ACKNOWLEDGEMENT}

We would like to thank LPPM Universitas Jenderal Soedirman for the funding this research on scheme Riset Institusi 2016.

\section{REFERENCES}

Ahmad, S., \& Hasanuzzaman, M. (2012). Integrated Effect of Plant Density, N Rates and Irrigation Regimes on the Biomass Production, $\mathrm{N}$ Content, PAR Use Efficiencies and Water Productivity of Rice Under Irrigated Semiarid Environment. Not. Bot. Horti. Agrobo., 40(1), 201-211. Retrieved from www.notulae botanicae.ro

Aliksa Organik SRI Consultan, [AOSC]. (2009). Pertanian ramah lingkungan melalui metoda system of rice intensificatioan. Modul Training of Trainer. Banda Aceh.

Andayani, \& Sarido, L. (2013). Uji Empat Jenis Pupuk Kandang terhadap Pertumbuhan dan Hasil Tanaman Cabai Keriting (Capsicum annum L.). AGRIFOR, 12(1), 22-29. Retrieved from https://media.neliti.com/ media/publications/30076-ID-uji-empat-jenispupuk-kandang-terhadap-pertumbuhan-danhasil-tanaman-cabai-kerit.pdf

Azis, A., Muyassir, \& Bakhtiar. (2012). Perbedaan Jarak Tanam dan Dosis Pupuk Kandang terhadap Sifat Kimia Tanah dan Hasil Padi Sawah (Oryza sativa L .). Jurnal Manajemen Sumberdaya Lahan, 1(2), 120125.

Bachtiar, T., Waluyo, S. H., \& Syaukat, S. H. (2016). Pengaruh Pupuk Kandang dan SP-36 terhadap Pertumbuhan Tanaman Padi Sawah. Jurnal Ilmiah Aplikasi Isotop dan Radiasi, 9(2), 151-159. https://doi.org/10.17146/JAIR. 2013.9.2.2739

Balai Besar Penelitian Tanaman Padi, [BBPADI]. (2013). Pengelolaan Tanaman Terpadu (PTT) Padi Lahan Sawah Irigasi. Subang, Jawa Barat: Badan Penelitian dan Pengembangan Pertanian, Kementerian Pertanian. Retrieved from http://bbpadi.litbang.pertanian.go.id/ index.php/publikasi/panduan-teknis/ pengelolaan-tanaman-terpadu-ptt-padi-lahansawah-irigasi

Bustami, Sufardi, \& Bakhtiar. (2012). Serapan Hara dan Efisiensi Pemupukan Phosfat serta
Pertumbuhan Padi Varietas Lokal. Jurnal Manajemen Sumberdaya Lahan, 1(2), 159-170. https://doi.org/10.1145/1041624. 1041664

Chaudhary, R. C. (2003). Speciality Rices of The World: Effect of WTO and IPR on Its Production Trend and Marketing. Journal of Food Agriculture and Environment, 1(2), 3441. Retrieved from http://agris.fao.org/agrissearch/search.do?recordID=FI2016100515

Christanto, H., \& Agung, I. G. A. M. S. (2014). Jumlah Bibit Per Lubang dan Jarak Tanam Berpengaruh terhadap Hasil Padi Gogo (Oryza sativa L.) dengan System of Rice Intensification (SRI) di Lahan Kering. Bumi Lestari Journal of Environment, 14(1), 1-8. Retrieved from https://ojs.unud.ac.id/index. $\mathrm{php} / \mathrm{blje} /$ article/view/11210

Ehsanullah, Jabran, K., Asghar, G., Hussain, M., \& Rafiq, M. (2012). Effect of Nitrogen Fertilization and Seedling Density on Fine Rice Yield in Faisalabad, Pakistan. Soil and Environment, 31(2), 152-156.

Fahmi, A., Utami, S. N. H., \& Radjagukguk, B. (2010). Pengaruh Interaksi Hara Nitrogen dan Fosfor terhadap Pertumbuhan Tanaman Jagung (Zea mays L) pada Tanah Regosol dan Latosol. Berita Biologi, 10(3), 297-304. https://doi.org/10.14203/beritabiologi.v10i3.7 44

Gani, A. (2003). Pedoman Praktis Bercocok Tanam Padi Sawah dengan Sistem SRI.

Gardner, F. P., Pearce, R. B., \& Mithcell, R. L. (1991). Fisiologi Tanaman Budidaya. Universitas Indonesia Press. Retrieved from https://books.google.co.id/books/about/Fisiol ogi_tanaman_budidaya.html?id=ygfdngEAC AAJ\&redir_esc=y

Gurjar, G. N., Swami, S., \& Meena, N. K. (2018). Effect of Age of Seedling and Number of Seedlings per Hill on Growth and Yield of Low land Rice Cultivation in Asia - A Review. International Journal of Current Microbiology and Applied Sciences, 7(06), 3751-3760. https://doi.org/10.20546/ijcmas.2018.706.439

Hakeem, K. R., Ahmad, A., Iqbal, M., Gucel, S., \& Ozturk, M. (2011). Nitrogen-efficient Rice Cultivars can Reduce Nitrate Pollution. Environmental Science and Pollution 
Research, 18(7), 1184-1193. https://doi.org/ 10.1007/s11356-010-0434-8

Hartatik, W., \& Widowati, L. R. (2005). Pengaruh Kompos Pupuk Organik yang Diperkaya dengan Bahan Mineral dan Pupuk Hayati terhadap Sifat-sifat Tanah, Serapan Hara, dan Produksi Sayuran Organik.

Hutasoit, T., Yetti, H., \& Yulia, A. E. (2015). Pengaruh Jumlah Bibit pada Lubang Tanam dan Frekuensi Pengendalian Gulma terhadap Pertumbuhan dan Produksi Padi Sawah (Oriza sativa L.) dengan Metode SRI. Jurnal Online Mahasiswa Fakultas Pertanian Universitas Riau, 2(1), 1-11. Retrieved from https://www. neliti.com/publications/202940/pengaruhjumlah-bibit-pada-lubang-tanam-danfrekuensi-pengendalian-gulma-terhada

Juarsah, I. (2014). Pemanfaatan Pupuk Organik untuk Pertanian Organik dan Lingkungan Berkelanjutan I. In Prosiding Seminar Nasional Pertanian Organik (pp. 127-136). Bogor.

Kaya, E. (2014). Pengaruh Pupuk Organik dan Pupuk NPK terhadap $\mathrm{pH}$ dan K-Tersedia Tanah Serta Serapan-K, Pertumbuhan, dann Hasil Padi Sawah (Oryza sativa L ). BUANA SAINS, 14(2), 113-122. https://doi.org/ 10.33366/BS.V14I2.353

Kristamtini. (2009). Mengenal Beras Hitam dari Bantul. Yogyakarta: Balai Pengkajian Teknologi Pertanian (BPTP).

Kristamtini, Taryono, Basunanda, P., \& Murti, R. H. (2014). Keragaman Genetik dan Korelasi Parameter Warna Beras dan Kandungan Antosianin Total Sebelas Kultivar Padi Beras Hitam Lokal. Ilmu Pertanian, 17(1), 90-103.

Lakitan, B. (2000). Dasar-Dasar Fisiologi Tumbuhan. PT Raja Grafindo Persada. Retrieved from https://books.google.co.id/ books/about/Dasar_dasar_fisiologi_tumbuhan .html $? \mathrm{id}=\mathrm{j}$ TuSnQAACAAJ\&redir_esc $=$ y

Masdar, \& Kasim, M. (2009). Pengaruh Optimalisasi Bibit dan Pupuk Kandang Ayam terhadap Pertumbuhan Vegetatif Tanaman Padi Intensifikasi SRI. Agrista, 13(1), 14-20. Retrieved from http://www.jurnal.unsyiah. ac.id/agrista/article/view/951

Maulida, D. A. R., \& Arisoesilaningsih, E. (2013).
Dinamika Struktur Komunitas Vegetasi Liar dan Pertumbuhan Padi Hitam di Sawah Organik Kecamatan Kepanjen Malang. Biotropika: Journal of Tropical Biology, 1(1), 19-23. Retrieved from https://biotropika.ub. ac.id/index.php/biotropika/article/view/123

Misran, M. (2017). Efisiensi Penggunaan Jumlah Bibit terhadap Pertumbuhan dan Produksi Padi Sawah. Jurnal Penelitian Pertanian Terapan, 14(1), 39-43. https://doi.org/10.25181/jppt. v14i1.140

Munawar, A. (2011). Kesuburan Tanah dan Nutrisi Tanaman. Bogor: IPB Press.

Muyassir. (2012). Efek Jarak Tanam, Umur dan Jumlah Bibit terhadap Hasil Padi Sawah (Oryza sativa L.). Jurnal Manajemen Sumberdaya Lahan, 1(2), 207-212.

Rachman, A., Dariah, A., \& Santoso, D. (2006). PUPUK HIJAU. Bogor: Balai Penelitian Tanah. Retrieved from http://balittanah. litbang.pertanian.go.id/ind/dokumentasi/lainn ya/03pupuk hijau.pdf

Rahayu, A. Y., \& Harjoso, T. (2011). Aplikasi Abu Sekam pada Padi Gogo (Oryza sativa L.) terhadap Kandungan Silikat dan Prolin Daun serta Amilosa dan Protein Biji. Journal of Biota, 16(1), 48-55.

Salisbury, F. B., \& Ross, C. W. (1992). Fisiology tumbuhan. Dewan Bahasa dan Pustaka. Retrieved from https://books.google.co.id/ books/about/Fisiologi_tumbuhan.html?id=Xn MpngEACAAJ\&redir_esc $=\mathrm{y}$

Samekto, R. (2006). Pupuk Kompos. Yogyakarta: PT Citra Aji Parama.

Sari, R. P., Islami, T., \& Sumarni, T. (2014). Aplikasi Pupuk Kandang dalam Meminimalisir Pupuk Anorganik pada Produksi Padi (Oryza sativa L.) Metode SRI. Jurnal Produksi Tanaman, 2(4), 308-315. https://doi.org/10.21176/PROTAN.V2I4.111

Suardi, D., \& Ridwan, I. (2009). Beras Hitam, Pangan Berkhasiat yang Belum Populer.

Susilo, J., Ardian, A., \& Ariani, E. (2015). Pengaruh Jumlah Bibit Per Lubang Tanam dan Dosis Pupuk N, P dan K terhadap Pertumbuhan dan Produksi Padi Sawah (Oryza Sativa L.) dengan Metode SRI. Jurnal Online Mahasiswa Fakultas Pertanian Universitas 
Riau, 2(1), 1-15. Retrieved from https://www. neliti.com/publications/189736/pengaruhjumlah-bibit-per-lubang-tanam-dan-dosispupuk-n-p-dan-k-terhadap-pertum

Syakhril, Riyanto, \& Arsyad, H. (2014). Pengaruh Pupuk Nitrogen terhadap Penampilan dan Produktivitas Padi Inpari Sidenuk. AGRIFOR, 13(1), 85-92. Retrieved from https://media. neliti.com/media/publications/30059-IDpengaruh-pupuk-nitrogen-terhadappenampilan-dan-produktivitas-padi-inparisidenu.pdf

Syamsiyah, J., Mulud, S., \& Lilis, A. (2009). Efisiensi Pupuk P dan Hasil Padi (Oryza sativa
L.) pada Sawah Pasir Pantai Kulonprogo yang Diberi Zeolite. Jurnal Ilmiah Ilmu Tanah Dan Agroklimatologi., 6(1), 7-14.

Taiz, L., \& Zeiger, E. (2002). Plant Physiology. Sinauer Associate Inc.Publisher Sunderland, Massachusetts.

Thawait, D., Patel, A. K., Kar, S., Kumar, M. and, S., \& Meshram, M. R. (2014). Performance of Transplanted Scented Rice (Oryza sativa L.) Under SRI Based Cultivation Practices; A Sustainable Method for Crop Production. The Bioscan, 9(2), 539-542. Retrieved from www.thebioscan.in 